\title{
BUDDHISM AND PSYCHOTHERAPY: \\ ANNOTATED BIBLIOGRAPHY
}

\begin{abstract}
Summary
This annotated bibliography aims to point out the important sources for understanding the relationship between Buddhist teaching and modern psychotherapeutic practice. The primary interest of the paper concerns the relationship between Buddhist psychology and modern Western psychotherapy, while the secondary focus is on re-examining the relationship between (Zen) Buddhism and Gestalt Therapy. The annotated bibliography contains twenty-six titles: thirteen books, three collections and ten papers. Fourteen titles in total contribute to the topic of the relationship between (Zen) Buddhism and Gestalt. The bibliography highlights examples of successful integration of knowledge from the corpus of Buddhist psychology and meditative techniques within Western-type psychotherapeutic practice.
\end{abstract}

Keywords: Daoism, Buddhism, Zen Buddhism, Psychotherapy, Gestalt, Gestalt Therapy.

\section{Introduction}

In the first half of the last century, key Eastern concepts of thought, primarily Daoism, Buddhism, and Zen Buddhism, frequently appeared in Western literature. At the same time, numerous intellectuals from the predominantly Buddhist cultures of the Asian world started exploring psychoanalysis and psychotherapy of the Western tradition. ${ }^{1}$

This paper offers an insight into the literature that underlines the common characteristics of Buddhism and psychotherapy or, more precisely, the common points of Zen Buddhism and Gestalt Therapy. Although the terms Buddhism and psychotherapy sometimes seem vaguely defined by different authors, this paper will rely on the following conceptual frameworks: (I) Zen as a unique path of liberation (Watts, 1957: 21), and the human spirit and faith in the inner purity, good-

1 Daisetsu Teitaro Suzuki provided such an example in the book Zen Buddhism and Psychoanalysis. 
ness and integrity of the human soul or being (Suzuki, 1991: 40) ${ }^{2}$; (II) Gestalt Therapy as integrative and relational psychotherapy that synthesises three components: a personal experience in the context of a given situation, the search for understanding through what is obvious and discovered (rather than through the observer's interpretation) and dialogue (Mann, 2010: 4).

The authors discuss Buddhism and psychotherapy, Buddhism and Gestalt Therapy, Zen Buddhism and psychotherapy. At the same time, some of them seek to understand only the relationship between Zen Buddhism and Gestalt Therapy.

Buddhism and Zen Buddhism are neither religious nor spiritual concepts that enrich or impoverish psychotherapy. In the context of the topic, Buddhism and Zen Buddhism are seen as concepts of thought, anthropological, cultural and philosophical knowledge. They are also helpful and practically applicable to modern psychology and psychotherapy. The intention is not to raise the question about the applicability of Buddhist and Zen Buddhist knowledge in psychotherapeutic work. The intention is not to confront different opinions of experts (for which there is room), and to draw a conclusion by comparing arguments. ${ }^{3}$ Within one article, the intention is to point out a part of the articles/books that shed light on the relationship between the two philosophical and psychological traditions: Eastern (Zen) Buddhist and Western psychotherapeutic.

The bibliography follows the order of the English alphabet by the first letter of the first signed author's surname in case a group of authors presented one work. The titles by the same author are listed in chronological order. Short explanations, with occasional comments on each of the titles, leave the reader to assess which title is more or less directly relevant to the topic. The common importance of all the titles within the attached bibliography is that they provide broader references for further research in the same and/or related fields.

The titles cited in the footnotes or the chapters Introduction and Conclusion, without being listed in Annotated Bibliography, are listed in Additional Literature and Content.

2 Zen Buddhism can be further described as a view of life that does not belong to any category of modern Western thought, a method that is not religion, philosophy, psychology or science, an Indo-Chinese ideological direction that is not Daoism, Vedanta or Yoga (Watts, 1957: 21). Zen Buddhism crystallizes Eastern philosophical concepts, but it is not a philosophical system in the conventional sense because it did not originate under the influence of logic and analysis (Suzuki, 1991: 38). For the same reason, Zen is not a religion as it is not interested in dogma. It neither affirms nor denies God and does not care for the welfare of the soul (Suzuki, 1991: 39).

3 An additional explanation of Buddhism as a science, knowledge and auxiliary view of the world and life was provided by the XVII Karmapa of the Tibetan Kagyu School Trinley Thaye Dorje in the speech What is Buddhism? 


\section{Annotated Bibliography}

Aich, T. K. Buddha Philosophy and Western Psychology. In. Indian Journal of Psychiatry. Vol. 55. No. 2. 2013. 165-170.

In the third chapter of the paper, Aich notes that there was a significant collaboration between Buddhist thinkers and psychoanalysts in the middle of the 20th century. The author further mentions Jung, Fromm, Watts, Brach, Kornfield, Goldstein, and Salzberg among the first to try to integrate Buddhist teaching and psychology since the focus of both approaches is on healing joint human suffering overlapping in theory and practice.

Further in the chapter, the author talks about the contact between Buddhist teaching and the Western psychological traditions, such as phenomenological, psychoanalytic, humanistic, cognitive and existentialist tradition. Besides, Aich compares specific sets of Buddhist principles with cognitive-behavioural therapy, dialectical-behaviour therapy, and stress reduction therapy through attention training.

Slightly later, in the chapter related to other psychological traditions, the author looks back at Gestalt Therapy. Gestalt Therapy is firmly grounded in existentialist philosophy and Zen Buddhism. Gestalt is interested in the whole person, in the wisdom of proper understanding and phenomenological and experiential reality now and here in the physical, emotional, and mental categories, which makes it akin to the basic postulates of Zen Buddhism.

Aitken, R. Zen Practice and Psychotherapy. In. The Journal of Transpersonal Psychology. Vol. 4 No. 2. 1982. 161-170.

The author emphasises that he is a layman in the field of psychology and psychotherapy. Since he had spent actively eighteen months in conventional psychotherapy (the last six of which were effective), based on his own experience, he notes that psychotherapy is beneficial if, regardless of psychotherapeutic techniques, the result is relief from intense preoccupation (162).

The author seeks to understand the relationship between Zen Buddhist practices and psychotherapy, while emphasising that Zen Buddhism is not psychotherapy as its primary goals differ from psychotherapy in terms of its approach. ${ }^{4}$

4 Referring to his Zen teacher, Aitken says that the purpose of Zen is the perfection of character (162), which is the backbone for an interdisciplinary understanding of Zen and psychotherapy. After all, isn't psychotherapy also an exercise in character development? The author cites Zen master Zenkei Roshi according to whom Zen is adapted to people of excellent mental health (163). In this context, we can question, to some extent, the validity of the parallel be- 
Further through the paper, the author talks about the purposefulness of zazen for mental health, ego and growth, ego in the context of zazen, observer techniques, observation and attention, and transcendent consciousness. The paper is significant due to its critical re-examination of the connections, similarities and differences between the knowledge and techniques that we draw from both the theory and practice of Zen Buddhism and from psychotherapy.

Austin, J. H. Zen and the Brain: Toward an Understanding of Meditation and Consciousness. MIT Press. 1998.

The paper does not examine the interrelationships of Buddhism, Zen Buddhism, psychotherapy or certain psychotherapeutic schools. Austin states that enlightenment is the result of essential changes that the brain goes through and, as a neurologist, he wonders whether meditation helps and contributes to such a change (XIX). Although Zen is not observed through words but instead through experience (XX), the scientific approach is firmly secular. Zen is, however, more than a means to personal change (4). Citing the results of a survey that included trainers and practitioners of transcendental meditation, the author claims that the mystical path is not a substitute for psychotherapy, nor is psychotherapy a substitute for the mystical path (375). ${ }^{5}$

The second chapter provides a significant contribution, explaining meditation from the aspect of basic psychological mechanisms. The fourth chapter intends to define normal states of consciousness and their alternative expressions. The eighth chapter deals with the natural advanced stages of awakening and its social consequences (XX).

Barber, P. Living Gestalt Moments with Anna: A Spiritual Journey through Alzheimer's. In. Gestalt Review. Vol. 17, No. 3. 2013. 214-228.

Through a series of arguments in the paper, Barber explains the old belief that, in addition to being a perfect therapy, Gestalt is also a spiritual tradition similar to Zen Buddhism in terms of striving for wise, sanctified and mindful living. Besides, the common point of Zen and Gestalt is that both concepts seek to raise

tween Zen and psychotherapy, while the author's simultaneous impression that Zen and psychotherapeutic practices stand in a somewhat competitive relationship (163) leaves room for understanding Zen Buddhism as one of the psychotherapeutic techniques.

5 Analysis and discussions on the relationship between Zen Buddhism and transcendental meditation may be an additional issue irrelevant to this brief. However, the author's attitude towards understanding and defining the term mystical path is worth being mentioned. 
awareness of the dual nature of humans through the analysis of the real and the constructed, thus helping the individual understand their actual state (214).

Brownell, Ph. Gestalt Therapy: A Guide to Contemporary Practice. Springer Publishing Company. 2010.

The book is a practical manual for clinicians, counsellors, psychotherapists of various specialisations, Gestalt psychotherapists, and students of Gestalt Psychotherapy. The title is helpful primarily for already active professionals who strive for independent and additional professional training.

Referring to Eva Gold, Brownell underlines in the first chapter that Gestalt Therapy originated under Zen Buddhist and, in general, Eastern philosophical influence. Gestalt seeks to understand the importance of consciousness, subjective experience, mindfulness and the value of lived feelings in the same way in which Zen Buddhism does it (5).

According to Brownell, a multitude of authors and ideas had influenced Gestalt Therapy: the psychoanalysis of Freud, Horney, Rank and Reich, the field theory by Kurt Lewin, the philosophy of Aristotle and Kant, the phenomenology of Brentano, Husserl, Levinas and Merleau-Ponty, the existentialism of Hiedggerer, Kierkegaard, Tillich and Buber. At the same time, Gestalt was under the influence of several ideological concepts originating from Daoism and Buddhism (168). ${ }^{6}$

Although the founders of Gestalt did not study Daoism or Zen Buddhism in detail, Eastern thought was a helpful metaphor in the reflections of the early Gestaltists, as it dealt with the way of individual life. The importance of Eastern thought for the development of Gestalt is indisputable. Its value, evident in Gestalt concepts, is seen in the focus on method and action, taking into account the current flow of experience and awareness, acceptance of current reality and trust in the natural flow of events ${ }^{7}$ that, as such, lead to personal wholeness and healing (24).

Brownell, Ph. Handbook for Theory, Research, and Practice in Gestalt Therapy (2nd Edition). Cambridge Scholars Publishing. 2019.

The book is a collection of papers by several experts in the field of Gestalt Psychotherapy. The title aims to be a database on the effectiveness of Gestalt

6 Although secondary to this paper, a new question is whether and to what extent the Eastern (Daoist, Buddhist and Zen Buddhist) philosophical idea inspired the listed thinkers to develop their philosophical concepts.

7 Zhang Runmei provided more details on the term flow in the article On the Rationality of Li Zehou's Philosophical Viewpoint on "A Culture of Optimism". 
(XI). As such, the collection is essential primarily for health professionals and Gestalt psychotherapists.

In the context of the topic, we find a significant contribution in the fourth chapter, Useful Methodology in Gestalt Research (103-139), by Jelena Zeleskov Djoric. In the chapter Capturing Principles of Practical Qualitative Research: Gestalt Therapy and Zen Buddhism, the author does not focus on the issue of ideas or conceptual relationships between Zen Buddhism and Gestalt, but more precisely on Zen Buddhist principles and their applicability in qualitative research within Gestalt, offering the approach that might further assist Gestalt researchers.

Referring to Janesick's comparison of Zen and qualitative research perspective based on observation, interview and interpretation, the author emphasises that the three ideas derived from Zen philosophy (the idea of impermanence and change, the idea that separate existence does not exist and the idea of a peaceful relationship, comprehension and pain acceptance) could be related in parallel to a qualitative research perspective (104). Throughout the rest of the paper, the author argues for this position explaining how the attached research method can function within the scientific Gestalt framework.

Epstein, M. Thoughts without a Thinker: Psychotherapy from a Buddhist Perspective. Basic Books. 1996.

The paper cross-examines the relationship between Buddhist-type meditation and psychotherapeutic practice, analysing the importance of meditation in psychotherapy. It begins with a review that Eastern thought penetrated the Western idea of consciousness first as alternative teaching and then as an influence that inspired the work of Maslow, Fromm and Horney at different ages (23).

The author notes that mastering the technique of confronting and eradicating narcissism is one of the essential skills that Buddhism can teach Western psychotherapists (23). Western therapists have been able to identify the source of a person's neurotic condition although they have been incapable of developing a sustainable treatment for the problem. At this point, Buddhist philosophy encounters a possible field of contribution within Western-type psychotherapy (24).

Among the examples, Epstein cites a client whose joint endeavour of meditation and psychotherapy helped him accept himself and his feelings, free himself from self-condemnation, and gain the necessary self-confidence (109). Besides, he cites the example of a person who realised through meditation that he needed psychotherapy (124). 
The author refers to the research that shows that meditators can be prone to anxiety, just like people who do not meditate. Thus, he does not equate meditation with psychotherapy (119). Although the author claims that meditation can create the basis for successful psychotherapy (123) and is broader than psychotherapy itself as it deals less with the details of personal history and more with the problems of being (120), he emphasises that meditation cannot replace psychotherapy. Furthermore, the examples described in the study support the thesis that Buddhist meditation might be an applicable technique in the psychotherapeutic process.

Gaur, J. Buddhist psychology: Relating Buddhism to Modern Psychological Techniques. In. Buddhist Approach to Harmonious Families, Healthcare and Sustainable Societies. Hong Duc Publishing House. 2019. 531-538.

The author draws a parallel and points out the similarities between Buddhist knowledge and modern psychological and psychotherapeutic theories and practices, and claims that part of the credit for the development of modern Western psychology unquestionably belongs to Siddhartha Gautama as its first founder (532). Siddhartha's self-observation and analysis of different levels of psychological functioning and human behaviour are essential guidelines for modern psychology. Thus, as a mixture of psychoanalysis, humanistic, cognitive and existentialist psychology, Buddhism is similar to modern psychotherapy (533).

Throughout the paper, Gaur talks about the relationship between the Buddhist concept of consciousness and stress reduction therapy. Furthermore, the author analyses the relationship between Buddhist teaching and psychological schools and psychotherapeutic approaches such as Rational-Emotive and Cognitive Behaviour therapies, Default Mode Network, Psychoanalysis, Behaviourism, Solution-Focused Therapy, Rogerian Therapy and Dialectical Behavioural Therapy.

Defining psychotherapy as a field that focuses on the potentials of the human being rather than on pathology, he sees the importance of Buddhist psychotherapy in the fact that it comprehends life-suffering as a chance for the growth, change and development of human potential (535). The author defines the Zen Buddhist philosophical concept as additional support for Gestalt given that Gestalt Therapy (just like Zen much earlier) exploits techniques whose attention is focused on phenomenological and experiential reality in the present, both in terms of physical as well as in terms of emotional and mental (534).

Gold, E. Zahm, S. Buddhist Psychology and Gestalt Therapy Integrated: Psychotherapy for the 21st century. Melta Press. 2018. 
The authors advocate a psychotherapeutic approach that holistically integrates knowledge and ideas from Buddhist psychology into Gestalt's psychotherapeutic practice. The book examines the essential similarities between Buddhist psychology (the concept of consciousness and meditative practice) and the psychotherapeutic Gestalt method. Besides the common points, the book explains the difference between Buddhist and Gestalt psychology regarding their ultimate focus and goals.

By addressing human suffering, the book explains how universal views of Buddhist psychology and the focus of Gestalt Therapy on issues of the individual and relational could function together. The examples from the clinical practice described in the study complement the authors' theoretical observations while providing an example of how the proposed psychotherapeutic approach could be applied.

Contrary to traditionalist beliefs that psychotherapeutic self-improvement and spiritual maturation are two separate paths, Gold and Zahm advocate the view that psychological maturation and spiritual transformation are a united path to complete personal development. ${ }^{8}$

Gold, E. Zahm, S. Buddhist Psychology Informed Gestalt Therapy for Challenging Times. In. The Humanistic Psychologist. Vol. 48. No. 4. 2020. 373-377.

The term Buddhist Psychology Informed Gestalt Therapy (BPGT) also appears in the previous study. Gold and Zahm developed the term that, as such, refers to a systematised approach that seeks to integrate Buddhist and Gestalt ideas and implement psychologically relevant Buddhist teachings in the psychotherapeutic work of the Gestalt orientation (374). Relevant teachings of Buddhist psychology relate to the Buddhist understanding of instability and suffering (373).

Given that Buddhist psychology offers a path of psychological development, healing and transformation, the authors emphasise that they are interested in practically applicable Buddhist science of the mind within the psychotherapeutic Gestalt method, distancing themselves from belief systems that might exist in some religiously oriented branches of Buddhism (374).

Similar to the previous title and in the context of Gestalt Therapy, this book emphasises the practical application of meditative practice and Buddhist ideas of consciousness and suffering here and now. In conclusion, the authors refer to one

8 In the context of this title, it is worth mentioning two YouTube interviews with the authors: (I) Eva Gold about Gestalt Therapy \& Buddhist Psychology. (II) Humans of Gestalt. 
of the essential Buddhist teachings concerning humans, according to which every external source of security is unreliable in its ultimate essence and nature (376). ${ }^{9}$

Kawai, H. Buddhism and the Art of Psychotherapy. Texas A\&M University Press. 1996.

Kawai was one of the first initiators of Jungian psychoanalysis in Japan. The book neither estimates the correlation between the two philosophical ideologies: Zen Buddhism and Gestalt, nor seeks to explain the historical relationship between Zen Buddhism and psychoanalysis. By criticising some aspects of Jungian theory, the book at the same time provides an example of the integration of Jungian psychoanalysis within Zen Buddhist practice. Pointing out the contradictions between Zen Buddhism and Jungian psychology, Kawai says that he treated his clients by healing the non-ego rather than treating the ego. The book provides examples in which complaints and symptoms of the clients were presented through Koan (XIV).

Buddhism has developed various meditation methods in order to maintain full awareness of concentration and observation. According to the author, Buddhism moved towards and reached emptiness consciousness while refusing the middle zone. Kawai's impression is that, opposite to Zen Buddhism, Jungian psychology focuses on the image for the middle zone and interprets it in relation to the ego (106).

The differences arising from the comparison of Eastern and Western psychological and philosophical approaches leave space for a further re-examination of one system's roles within the other. Moreover, the author intends to achieve an extensive practical framework applicable to psychotherapy and clinical work.

Mann, D. Gestalt Therapy: 100 Key Points and Techniques. Routledge Taylor \& Francis Group. 2010.

The book came from the context of Gestalt Therapy and was intended for practitioners and students of Gestalt Therapy. The authenticity of the paper is already evident in the author's introductory remarks saying that each Gestalt therapist could find 100 authentic key points of Gestalt (XI). The book is a summary

9 Although the authors' primary interest is not to reconsider historical relations between Buddhism and Gestalt, they claim that Buddhist teaching significantly influenced the founders of Gestalt (374). Therefore, Gold and Zahm agree with the authors such as Brownell, Gaur, Mann and Wulf. The authors mentioned Sylvia Fleming Crocker and Peter Philippson as relevant references for the discussion. 
of observations gathered from throughout the author's professional psychotherapeutic Gestalt practice.

While explaining Gestalt, Mann does not omit the possibility of integrating Buddhist and Zen Buddhist psychology within Gestalt Therapy. Except that, the author leaves room for a re-examination of philosophical, ideological and historical roots of Gestalt (Holism, Existentialism, Phenomenology, Field Theory), always in the context of Daoist and Zen Buddhist ideological concepts (IX).

Mathers, D. Miller, M. E. Ando, O. Self and No-Self: Continuing the Dialogue between Buddhism and Psychotherapy. Routledge Taylor \& Francis Group. 2009.

The book contains eight chapters. It was created as a collection of papers by a group of experts in psychology, psychiatry, neurology, psychoanalysis and psychotherapy. It is vital to draw attention to the first two chapters and the titles: Buddhism and psychotherapy: A Dialogue. Psychotherapy and Buddhism: A Psychological Consideration of Key Points of Contact. Two Arrows Meeting in MidAir. Desire and the self: Reflections on J. M. Coetzee's Slow Man. On Zen and Amaeru: A Psychological Approach to Zen. The Ego in the Psychology of Zen: Understanding Reports of Japanese Zen Masters on the Experience of No-Self.

Rosenbaum, R. Zen and the Heart of Psychotherapy. Routledge Taylor \& Francis Group. 2015.

The author is a clinical neuropsychologist, psychotherapist and Zen practitioner. The book, as such, is a testimony inspired by his personal experiences. It is a unique check-up of the applicability of the theory through practice. The critical question is how psychotherapy practice and Zen practice could coexist authentically in someone's life without adding to or taking anything away from the other.

According to the author, the book helps us learn how to practice and experience life through exercise. Each chapter re-estimates specific effects of Zen and psychotherapy practised together as well as the final results of such practice in daily life (7). The author mentioned that the book was not only intended for psychotherapists, clinicians and experts, but also to demonstrate how we can bring life to each moment of our existence (8).

Rubin, J. B. Psychotherapy and Buddhism: Toward an Integration. Springer Science + Business Media. 1996. 
The author emphasises that neither Buddhism nor psychoanalysis are unified doctrinal systems. Buddhism is a non-theistic system of teaching, and Theravada is one of the most psychological branches of Buddhism (3). Although Rubin predominantly discusses the relationship between Buddhism and psychoanalysis by analysing self or meditation through a psychoanalytic perspective, the book offers many seemingly incidental yet essential observations. Among these is the observation that meditative techniques are exploited mainly by non-analytical therapies such as Gestalt and Autogenic Training (117).

By claiming that Buddhism and psychoanalysis are complementary (46), Rubin emphasises that his approach to the topic is dialogical. He critically looks at both: the problem of orientocentrism and eurocentrism within the profession, urging dialogue given that neither Buddhism nor psychoanalysis are the absolute truths. Both traditions are human creations whose purpose has been to serve and satisfy current human interests and needs in specific historical circumstances (6).

Schoen, S. A Note on Gestalt Responsibility and Buddhist Non-Attachment. In. Gestalt Journal. Vol. 7. No. 2. 1984. 70-75.

The article by Gestalt psychotherapist Stephen Schoen is a case study of a forty-five-year-old lawyer who saw himself as an unhappy spouse and a rejected lover. For the purposes of the article, the author points out that, in Buddhism, the connections and actions are in harmony with the situation of the moment and that their adequate understanding derives from their non-attachment to self. In contrast, Gestalt Therapy emphasises responsibility and authority of the individual for their own life through independent decision-making and acceptance of consequences under the decisions made.

Based on this example, Schoen draws a parallel between Buddhism and Gestalt Therapy, summarising that the relativism of self, which we find in the philosophy and psychology of Buddhism, contributes to an authentic understanding of responsibility within the Gestalt concept, in which responsibility is seen as a flow of adaptive actions taken at this moment.

Shonin, E. Van Gordon, W. Griffiths, M. D. The Emerging Role of Buddhism in Clinical Psychology: Toward Effective Integration. In. Psychology of Religion and Spirituality. Vol. 6 No. 2. 2014. 123-137.

The authors base their argumentation on theoretical grounds, supporting it with examples from clinical practice. The article provides a detailed insight into the Buddhist understanding of wisdom, deception, non-existence of self, non-at- 
tachment, impermanence, interconnectedness, emptiness, original nature of mind, meditation and consciousness. By analysing the ideas of generosity, patience and compassion, the article highlights different approaches in terms of how the Buddhist-Eastern vs Western traditions comprehend the ethical values listed above.

According to the article, the ideas rooted in the philosophy and psychology ${ }^{10}$ of Buddhism could significantly contribute to clinical treatments of various psychopathological conditions such as mood disorders, addiction disorders, and even schizophrenia (123). One example in the article describes a group of patients of Buddhist background whose group members had suffered from diabetes and depression in parallel. The authors noticed that those who underwent Buddhist group therapy ${ }^{11}$ experienced a significant reduction in anxiety during the regular treatment they were supposed to receive (127).

The transition of Buddhist psychology from East to West does not contribute to Western clinical practice, given that Buddhist teaching in the West is usually perceived as spiritual or religious. While trying to explain to which extent Buddhist techniques could be applied to the clinical practice interested in psychopathology and psychotherapy, the authors urge dialogue among theorists, psychotherapists and doctors. They call for the standardisation of Buddhist terminology. Besides, the authors suggest a deeper discussion on how specific Buddhist techniques can improve contemporary clinical practice (133).

Shrobe, R. An exploration of the Zen Koan and Gestalt Impasse. In. Primary Point. Vol. 3. No. 3. 1986. 4-13.

According to Shrobe, Zen Koan and Gestalt are both focused on the same point due to what he considers the two traditions parallel processes. Both Zen and Gestalt lead to an experience of disorganisation and emptiness, showing new perspectives of the world. By exploiting its techniques, Zen aims to maintain a calm mind, leading to an intense experience of energy centralisation and unification. While Gestalt has the same goal as Zen, it relies more upon developmental psychology. By arguing that Gestalt Therapy is applied Zen, Strobe concludes that both disciplines could improve each other, creating a unique theoretical and practical system (13).

By referring to other authors according to whom the Zen tradition impacted Gestalt therapy, the author underlines that the goal of the article is to find the parallels between Zen Buddhism and Gestalt Therapy (4). Since the author used to work as a psychotherapist, he noticed the interests of some clients in eastern spir-

10 The authors use the term BDIs which stands for Buddhist-Derived Interventions (123).

11 The authors use the term BGT which stands for Buddhist Group Therapy (127). 
itual concepts. Theoretical knowledge of the traditions such as Zen Buddhism and Koan is additionally helpful for Gestalt therapists who work with those interested in Eastern philosophical concepts, and at the same time, seek help within Gestalt therapy (4).

Steggles, S. Holland, C. Fehr, R. Gestalt Therapy and Eastern Philosophies: A Partially Annotated Bibliography. In. Journal of Humanistic Psychology. Vol. 23. No. 2. 1983. 119-128.

The article is important for the topic as it lists titles that reconsider the relationship between different Eastern philosophical systems and Gestalt Therapy. Regarding Eastern philosophical systems, the listed articles discuss Buddhist and Zen Buddhist philosophical and psychological ideas in the context of Gestalt. Some articles focus on Eastern, Buddhist and Zen Buddhist historical roots of the Gestalt, while some of them are interested in the integration of the two approaches: Eastern philosophy on the one hand and the ideas of the Gestalt school on the other.

The annotated bibliography, divided into primary, secondary and tertiary, contains 52 titles published in English between 1947 and 1979. The bibliography includes 12 books, 21 chapters and 19 professional papers. Twelve titles within the primary and secondary bibliography serve as a basis for understanding the relationship between (Zen) Buddhism and Gestalt.

Tift, B. Already Free: Buddhism Meets Psychotherapy on the Path of Liberation. Sounds True. 2015.

As a practitioner, Tift combines Western psychotherapy and traditional Buddhism. According to the author, the combination of the two traditions offers guidance on how to remove oneself from suffering and how to experience freedom already present in our lives (9).

The book contains eight chapters. The first chapter is a theoretical review of Western psychology. The second chapter reviews the Buddhist ideas of freedom, while the third is an attempt at dialogue between the first two approaches based on Tift's clinical experience. The fourth chapter talks about anxiety and the fifth about awareness. Chapters six and seven deal with relationship issues. Chapter eight defines a state of mind free of the past and current circumstances and, as a result, focused on the present feelings. The described state of mind increases a sense of self-confidence and freedom, helping individuals to cope constructively with themselves, with others, and with life challenges at large. 
Wang, K. Spirit of Chinese Poetics. Foreign Languages Press. 2008.

Parts of the second and sixth chapters (Confucius and Plato on Music and Poetic Wisdom in Zen Enlightenment) are important for the psychological analysis of humans from the standpoint of Daoism, Confucianism, Buddhism and Zen Buddhism. To understand the commonalities and/or shared points of Buddhism and Zen Buddhism on the one hand, and modern psychology and psychotherapy on the other, we must bear in mind that Buddhism and Zen Buddhism possess authentic anthropology, cosmology and cosmogony. In addition to the theory of the natural laws, ecosystems, and the human place within them, they define a healthy mental state and the ultimate achievements of personal development within the described laws. ${ }^{12}$

In order to achieve the ideal personality, Confucius suggested a two-dimensional type of art education. The horizontal personal development could be achieved through sticking to the Dao (Way), basing oneself on the De (virtue), leaning upon the Ren (reciprocal human-heartedness) and taking free recreation through the practice of the six arts (40). By doing so, the individual attains a healthy mental state supported by the Dao in an ontological sense, supported by the De in a virtuous and moral sense, and strengthened by the Ren in a psychological sense. Poetry inspires the mind, the rite establishes the character, and music contributes to upbringing, leading to the complete and entire development of the character (40).

As the allegorical and symbolic wisdom of human existence, Zen is a poetic exposition essentially oriented towards liberation. It focuses on self-control, self-concentration, and self-enlightenment, helping the individual bridge the gap between real and ideal while leading people to face their fears (anxiety) and dissatisfactions (frustrations) with ease. Zen philosophy is oriented towards psychological balance and joy, enabling the individual to reach a mental state of intrinsic purification, proper satisfaction and peace (129).

Watson, G. Beyond Happiness: Deepening the Dialogue between Buddhism, Psychotherapy and the Mind Sciences. Karnac Books Ltd. 2008.

In the light of modern neurology and in order to respond to an individual's need for life satisfaction, Watson intends to open a discussion between Buddhist thought and psychotherapy. The second part of the book provides a signifi-

12 In the article Chinese Traditional Religions and Mental Health: An Indigenous Psychology Perspective, Rachel Sing-Kiat Ting, Siew-Chung Mah and Kejia Zhang provided a detailed insight into the culture of mental health in light of Chinese social, historical and religious context. 
cant contribution to the topic, as it analyses Buddhist meditation in the context of both: older scientific ideas and the scientific achievements of modern psychology and psychotherapy. In the second part of the book, the author says that she will consider essential aspects of our experience of embodiment, emotions, environment and self (XII). The author talks about different meditative practices derived from different Buddhist traditions when underlining the importance of meditation in the context of mental health.

\section{Watts, A. Psychotherapy: East and West. Pantheon Books Inc. 1961.}

From today's perspective, the book represents a classic within the theme that analyses the philosophies of the Eastern tradition and their common points with the psychotherapy of the Western tradition. Almost all the research dealing with Buddhism and Zen Buddhism in the context of psychotherapy does not avoid the contribution and significance of this title.

Although the author says that Zen Buddhism is neither psychology nor science (Watts, 1957: 21), (Zen) Buddhist concepts such as the ideas of liberation and holism could be found in the West only in Gestalt theory (129).

The book does not contribute significantly to the theoretical review of the relationship between Buddhism and Gestalt, given that Gestalt was a little-known nascent school during the fifties and sixties of the last century. Watts' contribution is, however, immeasurable in terms of its philosophical approach that, in the context of psychology and psychotherapy, provides useful insights into Daoism, Buddhism, Mahayana, Zen Buddhism and other philosophical traditions dominant primarily in the Eastern world.

Wright, R. Why Buddhism Is True: The Science and Philosophy of Meditation and Enlightenment. Simon \& Schuster. 2017.

The book does not analyse the supernatural elements of Buddhist teaching. Instead, it focuses on the scientific elements of the teaching, questioning the components of specific Buddhist theories with the knowledge we find in modern psychology and the knowledge practiced in modern psychotherapeutic schools. Given that Buddhism implicates many branches and schools (XIII), Wright is one of those authors who suggest that Buddhism cannot be described as a unified teaching system. As it is acceptable to talk about Buddhisms rather than about only one Buddhism, the author focuses on the common teachings of all schools, thus analysing the empirical relevance of these teachings from the standpoint of evolutionary biology and psychology. In the context of the topic, the author defines 
evolutionary psychology as a theory that tries to explain how the human brain was created by natural selection, not just to deceive and mislead humans but even to capture and enslave them (3).

Furthermore, Wright gives examples of everyday deceptions, drawing a parallel between the Buddhist understanding of deception and the phenomenon of deception explained by evolutionary psychology. In this context, the fourth chapter observes the brain modularity theory (also known as Default Mode Network or $D M N$ ). He further claims that the idea within the stated theory coincides with the Buddhist teaching about the non-existence of self and that, as such, it successfully explains the Buddhist understanding of self in a scientific and psychological sense. Since modern psychology provides a scientific foundation for the Buddhist understanding of the human psychological state, Wright also explains in detail the mental benefits of Buddhist meditation of consciousness.

Although, the book is not a strictly academic contribution. it, nevertheless, provides a sturdy argumentation that helps to understand the compatibility of Buddhist psychology with modern psychological and psychotherapeutic theories. The book does not deal with the history of psychoanalysis, modern psychology and psychotherapy, nor does it leave room for the conclusion that modern psychology and psychotherapy in any way draw their roots from Daoism, Buddhism or Zen Buddhism. However, it is one of the most important titles for the topic as it creates space for questioning the practical inclusion of Buddhist and Zen Buddhist teachings within modern psychotherapeutic practices. ${ }^{13}$

\section{Wulf, R. The Historical Roots of Gestalt Therapy Theory. In. Gestalt Dia-} logue: Newsletter for the Integrative Gestalt Centre. 1996.

The article provides an insight into the historical development of Gestalt, underlining its Daoist and Buddhist origins. The author takes a look at the professional development of Fritz Perls, Laura Perls and Paul Goodman and the ideological influence that Moreno, Friedlander, Horney, Reich, Fromm, Reichmann and Rank had on the founders of the Gestalt school. The author does not omit the

13 The online educational platform Coursera, in cooperation with Princeton University and Robert Wright, has presented a six-week course that is almost identical in content to parts of the book. The course Buddhism and Modern Psychology is available for free on the platform.

Besides Robert Wright, author and therapist Isa Gucciardi (isagucciardi.org) makes a significant contribution to the practical application of Buddhist psychology through her clinical and psychotherapeutic practice. Gucciardi has developed an authentic approach to the client, combining cultural and linguistic anthropology, comparative religion, and transpersonal psychology. There are two YouTube presentations worth mentioning for our topic: (I) Applied Buddhist Psychology with Isa Gucciardi, Ph.D. (II) Applied Buddhist Psychology: Buddha Nature with Isa Gucciardi, Ph.D. 
historical context in which Gestalt had been developing and the later contribution to Gestalt by Wertheimer, Koffka, Kohler and Lewin.

Wulf claims that Perl had learned about Zen Buddhism along with Wilhelm Reich. In addition, the author argues that most thinkers, who ideologically influenced Perl's articulation of the Gestalt concept, used to study diligently Eastern philosophies, especially Daoism and Zen Buddhism. Wulf thus concludes that the root of Gestalt can be undoubtedly found in the two philosophical traditions. ${ }^{14}$

Young-Eisendrath, P. Muramoto, Sh. Awakening and Insight: Zen Buddhism and Psychotherapy. Brunner-Routledge Taylor \& Francis Group. 2002.

The publication is a collection of articles published by several authors. For our topic, six articles in the first part of the book are of high priority: specifically the articles Buddhism, Religion and Psychotherapy in the World Today and in addition Jung and Buddhism in the second part of the publication.

According to Shoji Muramoto, Buddhism is usually taken as one of the representative religions of the East, while psychotherapy is seen as a scientific technique of the West for healing mental diseases (15). The author raises an essential question and wonders if psychotherapy is just of the West. To search for salvation is in the nature of humanity and, thus, psychotherapy could not belong to one part of the world. In this context, the author suggests an authentic insight according to which Buddhism, through its Sutras and Zen texts, has psychotherapeutic elements and should be seen as an Eastern version of psychotherapy (17).

The article Jung and Buddhism by the same author analyses the historical Jung in his relationship to Buddhism. The main questions of the article concern historical, ideological and personal contexts in which Jung got familiar with Buddhist teaching. Furthermore, Muramoto tends to come to terms with Jung's personal motifs as well as whether, how and to which extent Buddhism modified his views throughout his life (119).

For possible further research, it is also worth mentioning the texts What is I? Reflections from Buddhism and Psychotherapy in the second part and The Problematic of Mind in Gotama Buddha in the third part of the collection.

14 Gestalt therapist Jutta Keijo Pieper shares similar opinions on the historical connections between Zen Buddhism and Gestalt in the article Gestalt Psychotherapy and Zen, Similarities and Differences. The text is available on the website of the organisation Stonewater Zen Sangha (stonewaterzen.org). 


\section{Conclusion}

This annotated bibliography shows that the integration of Buddhist psychology and the modern psychotherapeutic approach is possible, and sometimes desirable. Although there is room for further discussions at the academic level (models and contexts of application, etc.), a positive answer to the question about the integration of the two philosophical systems is well-founded.

Is the Daoist, Buddhist and Zen Buddhist philosophical and psychological corpus the root of modern psychotherapeutic practices or, more precisely, is it enrooted in the Gestalt school? The question should be left open, not only because the information obtained can be interpreted in different ways but also because the importance of the answer to the question is unclear. Whether Daoist, Buddhist and Zen Buddhist thought influenced Western psychotherapeutic traditions or not, the importance of psychotherapeutic practice is neither strengthened nor weakened. Finally, it is theoretically possible to assume that both traditions emerged independently of each other.

The Buddhist psychology of the East and the contemporary psychotherapy of the West often differ in their approaches and primary interests. At the same time, due to what connects them, Western psychotherapy might look like a mirror image of Buddhist psychology and vice versa. The ideological founder of Buddhism did not try to be a psychotherapist. The significance of his mission lies in his intention to share his story based on his experience. If it sounds excessive to say that Buddhism was psychotherapy before psychology (in terms of its traditional understanding), it is certainly appropriate to say that Buddhism was at least the first life coaching ever. Buddhist teaching seeks to train us to live a life accessible to the senses, but at the same time not to omit the broader benefit of a clearly defined system of ethical values.

Siddhattha Gotama did not conduct experiments. He did not write down his observations, although it is indisputable that he had been speaking for years. He did not conduct empirical research, although he noticed that the experiment applied to himself worked. He did not tell us what to believe in or what to reject. He called for the path of discovering one's own truth: sometimes relative, but always authentic and unique.

He called for the path of awakening, liberation and understanding of the human condition. The need to experience awakening and liberation, the need to call the state of human existence by its proper name, might be a universal human need, rather than a topic that specifically Buddhism, modern Western psycholo- 
gy, or any systematically organised philosophical concept have always been interested in. Siddhattha had discovered his own path. He set an example according to which a voluntarily committed individual could find their own unique way to achieve peaceful authenticity.

\section{Additional Literature and Content}

Crocker, S. F. Philippson, P. Phenomenology, Existentialism, and Eastern Thought. In. Gestalt therapy: History, theory and practice. SAGE Publications. 2005. 65-80.

Dorje, T. T. What is Buddhism? Link: youtube.com/watch?v=r35_V5Y0G9Q\&ab_ channel=TheKarmapaDocumentaryProject.

Gold, E. Eva Gold about Gestalt Therapy \& Buddhist Psychology. Link: youtube.com/ watch? $\mathrm{v}=2 \mathrm{~K} 0 \mathrm{DhQ} 2 \mathrm{gAzM} \& \mathrm{t}=3 \mathrm{~s} \& \mathrm{ab}$ channel=RelationalImplicit\%26SomaticPsychotherapy.

Gold, E. Zahm, S. Humans of Gestalt. Link: https:/www.youtube.com/watch?v=2rPmo53ttYI\&t=11s\&ab channel=HumansofGestalt.

Gucciardi, I. Applied Buddhist Psychology with Isa Gucciardi, Ph.D. Link: youtube.com/ watch? $\mathrm{v}=0$ OTBsA1LWdA\&ab_channel=SacredStream.

Gucciardi, I. Applied Buddhist Psychology: Buddha Nature with Isa Gucciardi, Ph.D. Link: youtube.com/watch?v=iqVdTKTZqHw\&ab_channel=SacredStream.

Pieper, J. K. Gestalt Psychotherapy and Zen: Similarities and Differences. Link: stonewaterzen.org/2020/02/gestalt-psychotherapy-and-zen-similarities-and-differences-jutta-keijo-pieper/

Runmei, Zh. On the Rationality of Li Zehou's Philosophical Viewpoint on "A Culture of Optimism”. In. Proceedings: 2nd International Conference on Education Science and Economic Management. Advances in Social Science, Education and Humanities Research (ASSEHR). Vol. 184. 2018. 620-623.

Suzuki, D. T. Zen Buddhism and Psychoanalysis. Harper Collins. 1970.

Suzuki, D. T. An Introduction to Zen Buddhism. Grove Press. 1991.

Ting, R. Sing-Kiat. Mah, Siew-Chung. Zhang, K. Chinese Traditional Religions and Mental Health: An Indigenous Psychology Perspective. In. The Psychology of World Religions and Spiritualities. Templeton Press. 2020. 237-262.

Watts, A. The Way of Zen. Pantheon Books Inc. 1957.

Wright, R. Buddhism and Modern Psychology. Link: coursera.org/learn/science-of-meditation 


\title{
Nemanja D. Milinović
}

Nastavnik jezika. Trener veština upravljanja stresom.

ndmilinovic@gmail.com

\section{BUDIZAM I PSIHOTERAPIJA: ANOTIRANA BIBLIOGRAFIJA}

\begin{abstract}
Rezime
Anotirana bibliografija nastoji da ukaže na izvore važne za razumevanje odnosa između budističkog učenja i savremene psihoterapijske prakse. Primarno interesovanje rada je odnos između budisticke psihologije $i$ savremene psihoterapije zapadnog $t i-$ pa, dok je sekundarni fokus usmeren na procenjivanje odnosa i veza između (zen) budizma i Geštalt terapije. Anotirana bibliografija sadrži dvadeset šest naslova: trinaest knjiga, tri zbornika radova i deset tekstova. Ukupno četrnaest naslova doprinosi temi odnosa između (Zen) budizma i Geštalta. Bibliografija ukazuje na primere uspeřne integracije znanja iz korpusa budističke psihologije i meditativnih tehnika unutar psihoterapijske prakse zapadne tradicje.
\end{abstract}

Ključne reči: Daoizam, budizam, zen budizam, psihoterapija, Geštalt, Geštalt terapija. 